働き方をカエル?

〜ワーク・ライフ・バランスを考える〜

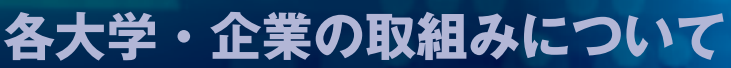

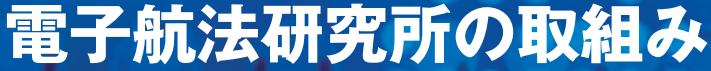

\section{— はじめに}

ワーク・ライフ・バランスを考える上で, 職務と生活の 境界を明らかにすることが必要であるが, 職務の分野によっ てはこれが意外に難しい. 特に, 研究職の場合, 職務とし て求められている報告の作成から資質向上のための日々の 勉学まで，職務の境界を設定しにくい．また，何らかの境 界を設定できたとしても，より良いバランスとするために は，本人の自覚，職場の規程とその運用，家族や地域など 生活環境，その他多くの要因を配慮する必要がある。本文 では, 比較的小規模な研究所・独立行政法人の例として, 独立行政法人電子航法研究所の状況を報告する.

\section{—研究所の概要}

当研究所の現状については, www.enri.go.jp に報告されて いるので，ここでは詳細を省略する，業務は，航空管制や 航空援助施設など，国が航空交通関倸のインフラストラク チャとして提供するサービスに必要な技術開発や評価を実 施している.

研究員は, 東京都調布市に勤務する。近隣に職員宿舎は あるが，職員の居所は多摩地区を中心に首都圏に散らばっ ている. 当研究所は JR や私鉄の駅からは数 $\mathrm{km}$ の距離にあ り, 近隣に住居がない限り通勤等には意外に時間が掛かる。 逆に，研究所近隣に居住する者は，語学学校などに通うに はそれなりに時間が掛かる。

小規模な当研究所の研究員は, 新人から管理職まで 50 人 弱である．担当する研究分野や段階に応じて業務の質は異 なるが, 研究段階は基礎的な調査から実用機器の評価のた めの試作プロジェクトまで, 研究分野は無線機器測定から 安全性分析などの数学的課題までと多岐にわたる。このた め, 業務量や拘束時間の分布幅が広い。

運営資金の大部分は国からの交付金に依存している。ま た，独立行政法人として人件費の削減対象であるが，研究 分野の特殊性から共同研究可能な相手は少なく, 外部との 連携等による「頭数」確保も容易ではない.

設立当時は運輸省の研究機関であり, 現在も国土交通省航 空局と業務のつながりが深い。研究員のほとんどは研究所採 用であるが，航空局との人事交流も行われている，女性職員 の比率が増加傾向にあり，正職員の研究員として 5 人が勤務
している.

独立行政法人の場合は, 合理的な理由を基にした理事長 の裁量により人事, 福利厚生制度を独自設定することは可 能ではあるが，もともと国家公務員の職場との関連も深い こと，少人数であるがゆえに人事関連の資金も限られてい ること, 更に, 上乗せの制度を設けるについては, 官・政 の目も厳しいことから, 職員の待遇は, 国家公務員と同等 にすることを基本としている。

\section{ロ ワーク・ライフ・バランス関連の制度}

ワーク・ライフ・バランスは, 個人的な生活から学業な ど研究者としての資質向上まで影響する。通勤時間から業 務の状況まで, 各人の多様な事情を配慮しながらの運用に 最も効果的なのは, 個人の裁量で活用できる時間の確保で ある。時間に着目すると, 1993 年に導入されたフレックス タイム制度が有用である。4 週間単位で勤務時間合計を一 定にする事前届出制で, 手続きを踏めば条件付きで届け出 後も変更可能である。この制度を活用し，大学院の社会人 課程に通う事例も見られる。

子供が満 3 歳に達した後の最初の 3 月 31 日まで育児休業 を取得できる。休業した期間は, その後の昇給や退職手当 などの計算をする際に換算をするが，在職期間に含まれる. その他，育览のための短縮勤務も制度化されている，介護 休業も，1 日単位または 1 時間単位で 1 日 4 時間まで，6か 月以内の期間内に取得できる。しかし, 特殊分野の小規模 研究所であるがゆえに, 専門分野の人員を一時確保するこ とが困難であり，業務量の波と休㗇を同期させることが課 題である.

自己啓発等の休業や妊娠，出産に関連した制度も，全般 的に国家公務員の制度を基本にしている．社会的に見て極 端に先進的ではないが，法令を着実に実現している。

\section{口まとめ}

小規模な独立行政法人は, 独自に待遇改善のための調査 をすることが資金的にも困難であるため, 人事院の調査結 果に頼っている. また，社会的にも国家公務員との比較が 論点となり, 結果的には人事院勧告準拠の待遇になる場合 が多い。まずは，フレックスタイムなど，勤務時間の柔軟 さを向上させることが効果的である.

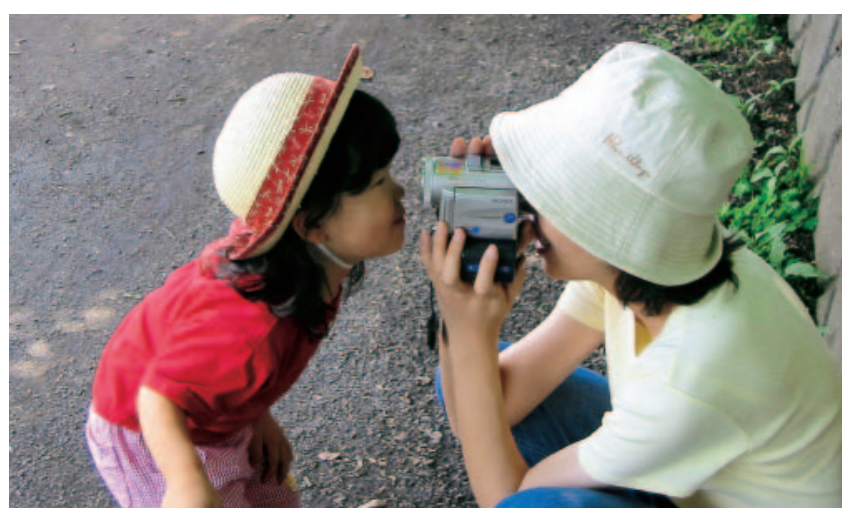

(文責：小瀬木滋) 